CAmbridge

\title{
BEST IN SCHOLARSHIP
}

\section{A History of Modern Burma}

Michael W. Charney

\$80.00: Hardback: 978-0-521-85211-1: 256 pp.

\$24.99: Paperback: 978-0-521-61758-1

The Idea of Indonesia

A History

R. E. Elson

\$105.00: Hardback: 978-0-521-87648-3: 394 pp.

The Politics of

Uneven Development

Thailand's Economic Growth in

Comparative Perspective

Richard F. Doner

\$80.00: Hardback: 978-0-521-51612-9: 344 pp.

\$24.99: Paperback: 978-0-521-73611-4

\section{Building Party Systems in} Developing Democracies

Allen Hicken

\$85.00: Hardback: 978-0-521-88534-8: 224 pp.

\section{Inventing Vietnam}

The United States and State Building, 1954-1968

James M. Carter

\$75.00: Hardback: 978-0-521-88865-3: 276 pp. \$22.99: Paperback: 978-0-521-71690-1

\section{Ghosts of War in Vietnam}

\section{Heonik Kwon}

Studies in the Social and

Cultural History of Modern Warfare

\$30.00: Hardback: 978-0-521-88061-9: 232 pp.

The Asian Military Revolution From Gunpowder to the Bomb

Peter A. Lorge

New Approaches to Asian History

580.00: Hardback: 978-0-521-84682-0: 200 pp.
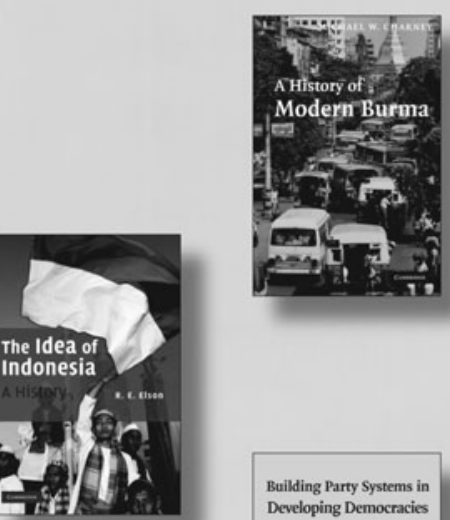

\$24.99: Paperback: 978-0-521-60954-8
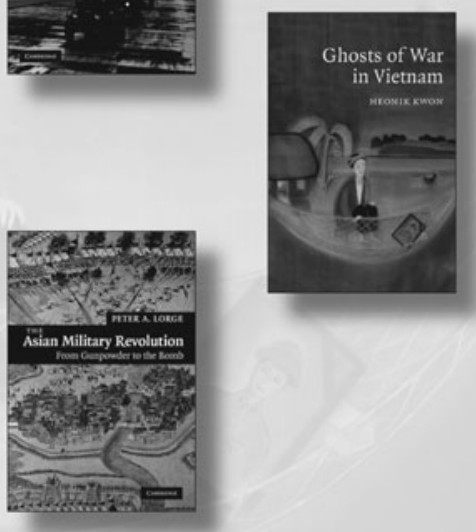

Prices subject to change.

www.cambridge.org/us 


\section{CAMBRIDGE}

\section{JOURNALS}

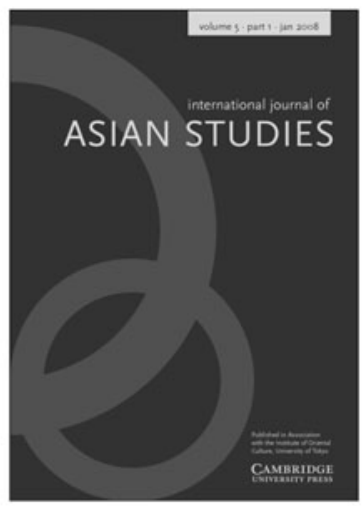

International Journal of Asian

\section{Studies}

is available online at: journals.cambridge.org/asi

To subscribe contact Customer Services

in Cambridge:

Phone $+44(0) 1223326070$

$\mathrm{Fax}+44(0) 1223325150$

Email journals@cambridge.org

in New York:

Phone (845) 3537500

Fax (845) 3534141

Email

subscriptions_newyork@cambridge.org

\section{International Journal of ASIAN STUDIES}

\section{Editors}

Takeshi Hamashita, Kyoto University, Japan Akinobou Kuroda, University of Tokyo, Japan Jason Webb, University of Tokyo, Japan Christian Daniels, Tokyo University of Foreign Studies, Japan Linda Grove, Sophia University, Tokyo, Japan Tsukasa Mizushima, University of Tokyo, Japan Kazuo Morimoto, University of Tokyo, Japan Katsuo Nawa, University of Tokyo, Japan

\section{International Journal of Asian Studies (IJAS) is an} interdisciplinary, English-language forum for research in the social sciences and humanities. IJAS examines Asia on a regional basis, emphasising patterns and tendencies that go beyond the borders of individual countries. Publishing writing from Asian and Western scholars alike, IJAS encourages communication across the international Asian Studies community.

Price information is available at: journals.cambridge.org/asi

\section{Free email alerts}

Keep up-to-date with new material sign up at journals.cambridge.org/register

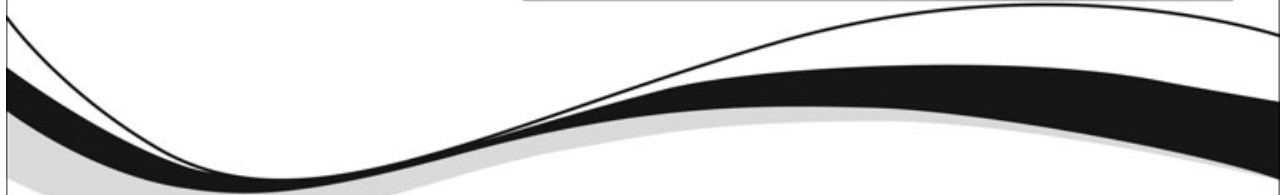

For a free online sample visit: journals. cambridge.org/asi 


\section{Copying}

This journal is registered with the Copyright Clearance Center, 222 Rosewood Drive, Danvers, MA 01923, USA. Organizations in the USA that are also registered with the C.C.C. may therefore copy material (beyond the limits permitted by sections 107 and 108 of U.S. Copyright law) subject to payment to the C.C.C. of the per copy fee of $\$ 12.00$. This consent does not extend to multiple copying for promotional or commercial purposes. Code 0022-4634/o6.

ISI Tear Sheet Service, 3501 Market Street, Philadelphia, PA 19104, USA, is authorized to supply single copies of separate articles for private use only. Organizations authorized by the Copyright Licensing Agency may also copy material subject to the usual conditions. For all other use, permission should be sought from Cambridge or from the American Branch of Cambridge University Press.

Articles appearing in the Journal of Southeast Asian Studies are abstracted or indexed in America: History and Life; Biography Index; Humanities Index; Historical Abstracts, Part A: Modern History Abstracts; Historical Abstracts, Part B: Twentieth Century Abstracts; Recently Published Articles (American Historical Association); ABC POL SCI; Petroleum Abstracts; Geographical Abstracts; Human Geography; International Development Abstracts; International Political Science Abstracts; Index of Islamic Literature.

Cover images: Journal of Southeast Asian Studies (2009-Volume 40)

Kneeling Figure with an Offering Vessel

Stoneware, Le Dynasty, $15^{\text {th }}$ century, possibly Cu Lao Cham, Quang Nam Province, Vietnam

$\mathrm{H} 22.7 \mathrm{~cm}, \mathrm{~W} 18.5 \mathrm{~cm}, \mathrm{D} 17 \mathrm{~cm}$

Asian Civilisations Museum, Singapore

Gift of Joe Grimberg and Rosalind Shellim in memory of Aaron Brooke David

Kneeling figures were part of the wide repertoire of Vietnamese blue-and-white ceramics that were made in northern Vietnam for export during the $15^{\text {th }}$ century. This rare example is thought to have been made for the Javanese market. His grotesque features, skirtwrap or kain panjang and ceremonial knife or keris tucked in at the waist, point to a Javanese source of inspiration. The figure recalls the Punakawan or clown court servants found in the Javanese theatre tradition. Their crude behaviour is underscored by words of wisdom for which they are highly revered.

Vietnamese potters were the only Southeast Asians to produce blue-and-white ceramics, as they had access to the cobalt pigment which may have been sourced from west Asia and China, as well as the technology to produce high-fired ceramics. They were also quick to seize the opportunity that arose when early Ming emperors banned the export of ceramics from China. Overseas demand was high and large quantities were produced for export, particularly to Southeast Asia. For example, the cargo that was excavated from Cu Lao Cham off the coast of Hoi An in central Vietnam in the late 1990s, comprised around 250,000 pieces. The high quality and unusual designs on the wares indicate that the clientele were discerning in their tastes and likely included the east Javanese court.

[This description was contributed by Heidi Tan, Senior Curator, Asian Civilisations Museum, Singapore]

Standing Kedah Buddha

Bronze, $5^{\text {th }} 9^{\text {th }}$ centuries, Kedah, Malay peninsula

$\mathrm{H} 20.6 \mathrm{~cm}, \mathrm{~A} 0134$

Asian Civilisations Museum, Singapore

The bottom panel displays a highly significant artefact affectionately known as the 'Kedah Buddha', after the north-western province of Malaysia where it was excavated. This bronze figure is thought to be one of the earliest images of Buddha to be found in the region.

It can be dated between the $5^{\text {th }}$ and the $9^{\text {th }}$ centuries of the Common Era, partly on the basis of Indian art styles of the Gupta period ( $4^{\text {th }} 6^{\text {th }}$ centuries). Indian images probably provided prototypes for Southeast Asian workshops. This figure was excavated from a site in the Bujang Valley or Lembah Bujang, (Malay for 'Dragon Valley'), north of Butterworth and home to a large complex of ancient brick structures built along several river networks. The valley was one of the earliest Hindu Buddhist settlements in the region, dating to the $4^{\text {th }}$ century and later became an important trading centre within the powerful maritime kingdom of Sri Vijaya.

The workmanship, which is less refined than Indian examples of this period, suggests it was unlikely to have come from India, but rather from local workshops, where presumably the process of interpreting and adapting new religious imagery or technological skills was still in the early stages. The lost wax method of bronze casting was used, in which the figure would have first been modelled in wax and then covered in a clay mould, before molten bronze was poured in to burn the wax away and assume the form of the figure. Certain attributes suggest that local artists had a keen eye for details. Carefully incised facial features, a series of folds on the back of the tightly clinging robes and the individually modelled hair curls, can easily be overlooked on first glance.

The graceful standing posture described by art historians as tribhanga (literally 'three bends' in Sanskrit), in which the hips sway to one side, is well known and one that is associated with early Buddhist images. The gesture of the extended right arm with palm open to the viewer, known as varada mudra ('boon-bestowing gesture'), signifies charity and the bestowal of favours. These attributes assume greater significance, when we consider the context in which it may have been used. The transmission of Buddhism from India to Southeast Asia during the early centuries may have been aided by the use of small portable icons, extolling the benefits of the faith. New ideas, like commodities, travelled along the trade routes used by merchants and took root in coastal trading centres. Dorothy and H. G. Quaritch Wales excavated some 30 sites along the Bujang and other rivers of this area and in the early 1940s, they reported that many of these were temple shrines or candi, most probably frequented by travellers on the inland waterways. Amongst the finds that were sent to museums overseas, a small collection of votive offerings in the form of miniature gold objects and clay votive tablets as well as this bronze figure were deposited at the Raffles Museum in Singapore. Today, the Kedah Buddha can be viewed at the Asian Civilisations Museum, which generously gave permission for the image to be published. 
Volume $40 \mid$ Number I | February 2009

\section{Journal of SOUTHEAST ASIAN STUDIES}

\section{Contents}

\section{Symposium on Buddhists in southern Thailand}

1 Introduction: Thai Buddhism, Thai Buddhists and the southern conflict

Duncan McCargo

\section{Articles}

11 The Politics of Buddhist identity in Thailand's deep south: The Demise of civil religion?

Duncan McCargo

33 Appropriating a space for violence: State Buddhism in southern Thailand

Michael Jerryson

59 Landscapes of fear, horizons of trust: Villagers dealing with danger in Thailand's insurgent south

Marc Askew

87 Making new space in the Thai literary canon

Thak Chaloemtiarana

111 Garuḍa, Vajrapāni and religious change in Jayavarman VII's Angkor Peter D. Sharrock

153 Semelai agricultural patterns: Toward an understanding of variation among indigenous cultures in southern peninsular Malaysia Rosemary Gianno and Klaus J. Bayr

187 Decent colonialism? Pure science and colonial ideology in the Netherlands East Indies, 1910-1929 Andrew Goss

Book Reviews

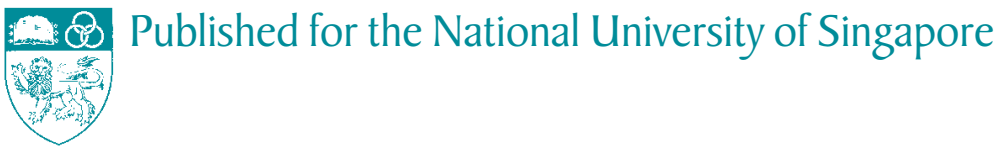

Cambridge Journals Online

For further information about this journal please

go to the journal web site at:

journals.cambridge.org/sea

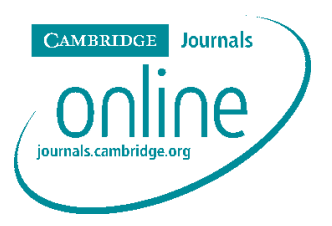

CAMBRIDGE UNIVERSITY PRESS 